\title{
Prize in History of Economics
}

We at Land Economics are delighted to announce that Spencer Banzhaf has won the Best Article in the History of Economics Prize for 2009, presented by the History of Economics Society, for his article "Objective or Multi-Objective? Two Historically Competing Visions for Benefit-Cost Analysis," published in Land Economics, volume 85, number 1 .

David Levy, chair of the Best Article committee at the History of Economics Society, had this to say:

For the past 15 years, the History of Economics Society has awarded a prize for the best article pub- lished in the previous year. This year there were over two dozen articles nominated. The committee selected Spencer Banzhaf's paper on benefit-cost analysis. One member, who described the paper as "fascinating," wrote a brief summary that nicely catches the contribution: "Banzhaf [studies how] the benefitcost instrument was itself the object of debate; and the outcome of that debate is cast as a reflection of fundamental differences in perceptions regarding the capacity of political institutions to reach socially optimal decisions regarding competing policy goals."

Daniel W. Bromley Editor

Land Economics • February 2011 • 87 (1): iii ISSN 0023-7639: E-ISSN 1543-8325

(C) 2011 by the Board of Regents of the University of Wisconsin System 


\section{GUIDELINES FOR MANUSCRIPT SUBMISSION}

LAND ECONOMICS has a Web-based manuscript submission system, which we began on January 1, 2007. Our system will ask you to register, and then you may submit your manuscript electronically. Once you are registered, future submissions will be simple and routine.

The link to our submission Web site is: http://le.msubmit.net/cgi-bin/main.plex. Once there, you will find all of the information you need-including format guidelines.

Thank you for your interest in LAND ECONOMICS.

For those unable to use our new procedures, we will still accept paper manuscripts. In that case please send three copies of the manuscript to Daniel W. Bromley, Editor; Land Economics; University of Wisconsin; Taylor Hall, 427 Lorch St.; Madison, WI 53706-1503. In a cover letter, the author should state that the manuscript being submitted has not been published nor is being considered for publication elsewhere. The cover letter should contain all pertinent contact information for the author responsible for correspondence with our editorial offices. Articles longer than 3035 pages will not be considered.

The manuscript should be double-spaced, on one side of the page only, with margins of one inch on all sides. Please include an abstract of 100 words on a separate page. Use the author-date system of citations in the body of the article and for the bibliography. See a current issue of LAND ECONOMICS for guidance. You may also wish to access our Web site: http://le.uwpress.org. All notes (footnotes) must be at the end of the manuscript as endnotes. Extensive mathematical material is discouraged, and if necessary, it should appear in a separate appendix. Tables and figures must be on separate pages.

It is the policy of LAND ECONOMICS to publish papers only on the condition that the data used in the analysis are (1) clearly and precisely documented, (2) readily available to any researcher for purposes of replication, and (3) sufficiently detailed in the specifics of computations to permit replication. Appearance of an article in LAND ECONOMICS constitutes evidence that authors understand these conditions and will abide by the stated requirements. 